\title{
Asas-Asas Umum Pemerintahan yang Baik dalam Pelayanan Publik
}

\author{
Solechan \\ Fakultas Hukum, Universitas Diponegoro \\ solechan@live.undip.ac.id
}

\begin{abstract}
AAUPB (Asas asas umum pemerintahan yang baik) has a long journey from the beginning of its birth in the Netherlands to its application in Indonesia today. AAUPB at first was only in the theoretical realm and then entered into law until AAUPB got a very important position in Law No. 30 of 2014. Initially, AAUPB was intended as a means of legal protection or rechtsbescherming, and was even used as an instrument to increase legal protection or rechtsbescherming for citizens from government actions. AAUPB is then used as the basis for judgments in the judiciary and administrative efforts, as well as an unwritten legal norm for government actions The history of the development of AUPB in Indonesia can be seen from the development of the AUPB principle in various laws and regulations, the practice of implementing the AUPB in court decisions or jurisprudence and doctrine. The development of the AUPB principle arrangement has found an increasingly strong momentum, when the Government Administration Act was passed in 2014. As a result of the adoption of the concept of the welfare state, the state has an obligation to fulfill the welfare of the community, one of which is through public services. With the AAUPB, it is expected that the government as a public service provider can accept the AAUPB as a legal norm that must be used as the basis by the public service provider in carrying out its authority, as well as a means for citizens to sue deviant public service providers.
\end{abstract}

Keywords: General principles of good governance, public service.

\begin{abstract}
Abstrak
Asas-asas umum pemerintahan yang baik (selanjutnya disebut AAUPB) lahir dari praktik penyelenggaraan negara dan pemerintahan sehingga bukan produk formal suatu lembaga negara seperti undang-undang. Asas-asas umum pemerintahan yang baik dapat dipahami sebagai asas-asas umum yang dijadikan sebagai dasar dan tata cara dalam penyelenggaraan pemerintahan yang layak, yang dengan cara demikian penyelenggaraan pemerintahan itu menjadi baik, sopan, adil, dan terhormat, bebas dari kezaliman, pelanggaran peraturan, tindakan penyalahgunaan wewenang dan tindakan sewenang-wenang. Sejarah perkembangan AUPB di
\end{abstract}


Indonesia dapat dilihat dari perkembangan prinsip AUPB dalam berbagai peraturan perundang-undangan, praktik penerapan AUPB dalam putusan pengadilan atau yurisprudensi serta doktrin. Perkembangan pengaturan prinsip AUPB menemukan momentumnya yang semakin kuat, tatkala UU Administrasi Pemerintahan disahkan pada tahun 2014. Sebagai akibat dari dianutnya konsepsi welfare state maka negara memiliki kewajiban untuk memenuhi kesejahteraan masyarakat salah satunya melalui pelayanan publik. Dengan adanya AAUPB diharapkan pemerintah sebagai pemberi pelayanan publik dapat menerima AAUPB sebagai norma hukum yang harus dijadikan dasar oleh penyelenggara pelayanan publik dalam menjalankan kewenangannya, sekaligus sarana bagi warga negara untuk menggugat penyelenggara pelayanan publik yang menyimpang.

Kata Kunci : Asas-asas umum pemerintahan yang baik, Pelayanan Publik

\section{A. Pendahuluan}

Pergeseran konsepsi nachtwachtersstaat (negara peronda) ke konsepsi welfare state membawa pergeseran pada peranan dan aktivitas pemerintah. Pada konsepsi nachtwachtersstaat berlaku prinsip staatsonthouding, yaitu pembatasan negara dan pemerintah dari keshidupan sosial ekonomi masyarakat. Pemerintah bersifat pasif, hanya sebagai penjaga ketertiban dan keamanan masyarakat. Sementara pada konsepsi welfare state, pemerintah diberi kewajiban untuk mewujudkan bestuurszorg (kesejahteraan umum), yang untuk itu kepada pemerintah diberikan kewenangan untuk campur tangan (staatsbemoienis) dalam segala lapangan kehidupan masyarakat. Artinya pemerintah dituntut untuk bertindak aktif ditengah dinamika kehidupan masyarakat.

Keberadaan konsep negara kesejahteraan dengan tujuannya untuk memberikan kesejahteraan bagi seluruh warga negara, adalah dalam rangka untuk melengkapi asas legalitas yang mana semua Aktivitas pemerintahan harus mendasarkan kepada peraturan perundangan. Sementara itu, dengan berkembangnya ilmu pengetahuan dan tekhnologi, maka sangat mungkin mempengaruhi pula terhadap dinamika perkembangan masyarakat dengan 
berbagai aktivitasnya, yang mana sangat mungkin terjadi untuk menangani masalah yang timbul, belum ada peraturannya. ${ }^{1}$

Setiap bentuk campur tangan pemerintah harus didasarkan pada peraturan perundang-undangan yang berlaku sebagai perwujudan dari asas legalitas, yang menjadi sendi utama negara hukum. Sejak dianutnya konsepsi welfare state, yang menempatkan pemerintah sebagai pihak yang bertanggung jawab terhadap kesejahteraan umum warga negara dan untuk mewujudkan kesejahteraan ini pemerintah diberi wewenang untuk campur tangan dalam segala lapangan kehidupan masyarakat, yang dalam campur tangan ini tidak saja berdasarkan pada peraturan perundang-undangan , tetapi dalam keadaan tertentu dapat bertindak tanpa bersandar pada peraturan perundang-undangan, tetapi berdasar pada inisiatif sendiri. Namun, disatu sisi keaktifan pemerintah dalam mengupayakan kesejahteraan umum haruslah senantiasa berdasarkan pada asas-asas umum pemerintahan yang baik (selanjutnya disebut AAUPB). ${ }^{2}$

Jimly berpendapat bahwa dalam paham negara hukum segala tindakan pemerintahan harus didasarkan atas peraturan perundang-undangan yang sah dan tertulis. Peraturan perundang-undangan tertulis tersebut harus ada dan berlaku lebih dulu atau mendahului tindakan atau perbuatan administrasi yang dilakukan. Dengan demikian, setiap perbuatan atau tindakan administrasi harus didasarkan atas aturan atau 'rules and procedures' $^{\prime}$ (regels). ${ }^{3}$

Fungsi asas-asas umum pemerintahan yang baik dalam penyelenggaraan pemerintahan adalah sebagai pedoman atau penuntun bagi pemerintah atau pejabat administrasi negara dalam rangka pemerintahan

\footnotetext{
${ }^{1}$ dyah Adriantini Sintha Dewi, 'Pendayagunaan Freies Ermessen Pejabat Pemerintahan Dalam Konsep Negara Kesejahteraan', 5.1 (2016), 184-94.

${ }^{2}$ Ridwan HR, HUKUM ADMINISTRASI NEGARA (PT RajaGrafindo Persada, Jakarta, 2014).

${ }^{3}$ Sadhu Bagas Suratno, 'Pembentukan Peraturan Kebijakan Berdasarkan Asas-Asas Umum Pemerintahan Yang Baik', E-Journal Lentera Hukum, 4.3, 164 <https://doi.org/10.19184/ejlh.v4i3.5499>.
} 
yang baik. Dalam hubungan ini, Muin Fahmal mengemukakan bahwa asas umum pemerintahan yang layak sesungguhnya adalah rambu-rambu bagi para penyelenggara negara dalam menjalankan tugasnya. Rambu-rambu tersebut diperlukan agar tindakan-tindakan tetap sesuai dengan tujuan hukum yang sesungguhnya. ${ }^{4}$

\section{B. Hasil Penelitian dan Pembahasan}

\section{Pengertian, kedudukan, dan fungsi dan arti penting AAUPB}

\section{a. Pengertian AAUPB}

Tindakan atau campur tangan pemerintah dalam konsep negara kesejahteraan (welfare state) sebagai pihak yang bertanggung jawab untuk mewujudkan kesejahteraan dan kemakmuran warga masyarakatnya semakin besar. Sebagai negara hukum, maka tindakan pemerintah untuk memberikan kesejahteraan tersebut juga harus berdasarkan peraturan perundang-undangan yang berlaku atau sering bertindak berdasarkan freies ermessen, namun tindakan tersebut sering menimbulkan penyalahgunaan wewenang yang mengakibatkan terjadi benturan kepentingan antara warga masyarakat dengan pemerintah.

Menurut Jazim Hamidi, berdasarkan rumusan pengertian para pakar dan tambahan pemahaman penulis (Jazim Hamidi) tentang AAUPB, maka dapat ditarik unsur-unsur yang membentuk pengertian tentang AAUPB secara komprehensif, yaitu : ${ }^{5}$

1. AAUPB merupakan nilai nilai etik yang hidup dan berkembang dalam lingkungan hukum administrasi negara

2. AAUPB berfungsi sebagai pegangan bagi Pejabat Administrasi Negara dalam menjalankan fungsinya, merupakan alat uji bagi hakim administrasi dalam menilai tindakan administrasi negara (yang

\footnotetext{
${ }^{4}$ Widjiastuti.

${ }^{5}$ Jazim Hamidi, Penerapan Asas-Asas Umum Pemerintahan Yang Layak (AAUPL) Di Lingkungan Peradilan Administrasi Indonesia. (Citra Aditya Bakti, Bandung, 1999).
} 
berwujud penetapan/beschikking), dan sebagai dasar pengajuan gugatan bagi pihak penggugat.

3. Sebagian besar dari AAUPB masih merupakan asas-asas yang tidak tertulis, masih abstrak, dan dapat digali dalam praktik kehidupan di masyarakat.

4. Sebagian asas yang lain sudah menjadi kaidah hukum tertulis dan terpencar dalam berbagai peraturan hukum positif. Sebagian asas telah berubah menjadi kaidah hukum tertulis, namun sifatnya tetap sebagai asas hukum.

Konsepsi AAUPB menurut Crince le Roy yang meliputi: asas kepastian hukum, asas keseimbangan, asas bertindak cermat, asas motivasi untuk setiap keputusan badan pemerintah, asas tidak boleh mencampuradukkan kewenangan, asas kesamaan dalam pengambilan keputusan, asas permainan yang layak, asas keadilan atau kewajaran, asas menanggapi pengharapan yang wajar, asas meniadakan akibat-akibat suatu keputusan yang batal, dan asas perlindungan atas pandangan hidup pribadi. Koentjoro menambahkan dua asas lagi, yakni: asas kebijaksanaan dan asas penyelenggaraan kepentingan umum. ${ }^{6}$

\section{b. Kedudukan AAUPB dalam Sistem Hukum}

Menurut Philipus M. Hadjon AAUPB harus dipandang sebagai norma-norma hukum tidak tertulis, yang senantiasa harus ditaati oleh pemerintah, meskipun arti yang tepat dari AAUPB bagi tiap keadaan tersendiri tidak selalu dapat dijabarkan dengan teliti. Dapat dikatakan bahwa AAUPB adalah asas-asas hukum tidak tertulis, dari mana untuk keadaan-keadaan tertentu dapat ditarik aturan-aturan hukum yang dapat diterapkan. ${ }^{7}$ Pada kenyataannya, AAUPB ini meskipun merupakan asas, namun tidak semuanya merupakan pemikiran yang umum dan abstrak, dan

\footnotetext{
${ }^{6}$ Muhammad Azhar, 'Relevansi Asas-Asas Umum Pemerintahan Yang Baik Dalam', Relevansi Asas-Asas Umum Pemerintahan Yang Baik Dalam Sistem Penyelenggaraan Administrasi Negara, 8.5 (2015), 274-87.

${ }^{7}$ Philipus M. Hadjon and Et.al, Pengantar Hukum Administrasi Indonesia (Yogyakarta: Gadjah Mada University Press, 1993).
} 
dalam beberapa hal muncul sebagai aturan hukum yang konkret atau tertuang secara tersurat dalam pasal undang-undang serta mempunyai sanksi tertentu. Apabila asas-asas umum pemerintahan yang baik dimaknakan sebagai asas atau sendi hukum, maka asas-asas umum pemerintahan yang baik dapat dimaknakan sebagai asas hukum yang digali dan ditemukan dari unsur susila, etika, kesopanan, dan kepatutan berdasarkan norma yang berlaku. ${ }^{8}$ Hal tersebut dapat dikatakan bahwa sebagian AAUPB masih merupakan asas hukum, dan sebagian lainnya telah menjadi norma hukum atau kaidah hukum. ${ }^{9}$

\section{c. Fungsi dan Arti penting AAUPB}

Pada awal kemunculannya, AAUB hanya dimaksudkan sebagai sarana perlindungan hukum dan dijadikan sebagai instrumen untuk peningkatan perlindungan hukum bai warga negara dari tindakan pemerintah. Fungsi asas-asas umum pemerintahan yang baik dalam penyelenggaraan pemerintahan adalah sebagai pedoman atau penuntun bagi pemerintah atau pejabat administrasi negara dalam rangka pemerintahan yang baik. Dalam hubungan ini, Muin Fahmal mengemukakan bahwa asas umum pemerintahan yang layak sesungguhnya adalah rambu-rambu bagi para penyelenggara negara dalam menjalankan tugasnya. Rambu-rambu tersebut diperlukan agar tindakan-tindakan tetap sesuai dengan tujuan hukum yang sesungguhnya.

AAUPB dapat di ibaratkan sebagai rambu lalu lintas dan pedoman perjalanan dalam rangka memperlancar hubungan pemerintahan yaitu antara pemerintah dan yang diperintah atau warga masyarakat. AAUPB selanjutnya dijadikan sebagai dasar penilaian dan upaya administrasi, di samping sebagai norma hukum tidak tertulis bagi tindakan pemerintah. ${ }^{10}$ Dalam perkembangannya, AAUPB memiliki arti penting dan fungsi sebagai berikut :

\footnotetext{
${ }^{8}$ SF. Marbun, Pembentukan, Pemberlakuan, Dan Peranan Asas-Asas Umum Pemerintahan Yang Layak Dalam Menjelmakan Pemerintahan Yang Baik Dan Bersih Di Indonesia (Bandung, 2001).

${ }^{9} \mathrm{HR}$.

${ }^{10}$ Widjiastuti.
} 
1. Bagi administrasi negara, bermanfaat sebagai pedoman dalam melakukan penafsiran dan penerapan terhadap ketentuan-ketentuan perundang-undangan yang bersifat sumir, samar atau tidak jelas. Kecuali itu sekaligus membatasi dan menghindari kemungkinan administrasi negara mempergunakan freies ermessen/ melakukan kebijakan yang jauh menyimpang dari ketentuan perundang-undangan. Dengan demikian, administrasi negara diharapkan terhindar dari perbuatan onrechtmatige daad, detournement de pouvoir, abus de droit, dan ultravires.

2. Bagi warga masyarakat, sebagai pencari keadilan, AAUPB dapat dipergunakan sebagai dasar gugatan sebagaimana disebut dalam pasal 53 UU No. 5 Tahun 1986.

3. Bagi Hakim TUN, dapat dipergunakan sebagai alat menguji dan membatalkan keputusan yang dikeluarkan badan atau Pejabat TUN.

4. AAUPB juga berguna bagi badan legislatif dalam merancang suatu Undang-Undang.

Menurut Indroharto, AAUPB merupakan bagian dari asas-asas hukum yang umum yang secara khusus berlaku dan penting artinya bagi perbuatan-perbuatan hukum pemerintahan. Arti penting dari keberadaan AUPB disebabkan oleh beberapa hal: ${ }^{11}$

1. AUPB merupakan bagian dari hukum positif yang berlaku;

2. AUPB merupakan norma bagi perbuatan-perbuatan administrasi Negara, di samping norma-norma dalam hukum tertulis dan tidak tertulis;

3. AUPB dapat dijadikan alasan untuk mengajukan gugatan, dan pada akhirnya AUPB dapat dijadikan "alat uji” oleh Hakim administrasi, untuk menilai sah atau tidaknya, atau batal atau tidaknya keputusan administrasi Negara

\footnotetext{
${ }^{11}$ Indroharto, "Asas-asas Umum Pemerintahan Yang Baik", dimuat dalam Paulus Effendi Lotulung (Ed.), Himpunan Makalah Asas-asas Umum Pemerintahan Yang Baik, Cet. Pertama, Citra Aditya Bakti, Bandung, 1994, hlm 145-146.
} 


\section{Perkembangan Asas-Asas Umum Pemerintahan Yang Baik}

Tata kelola pemerintahan yang baik selalu berkembang serta mengikuti perkembangan global, tidak mungkin hanya bersifat nasional saja. Penyelenggaraan pemerintahan adalah untuk memberi pelayanan publik kepada masyarakat, yang dipengaruhi oleh dinamika politik, ekonomi, perkembangan teknologi informasi, sosial budaya yang kesemuanya bercampur dan memberi pengaruh penyelenggaraan pemerintahan. $^{12}$

Penyelenggaraan pemerintahan di negara maju tentu berbeda dengan negara berkembang, beberapa faktor penting memberi pengaruh, yaitu cara berpikir yang mengutamakan kualitas pelayanan, transparansi, integritas, kapasitas pengembangan kemampuan dan didukung oleh hal lain bersifat non-teknis tetapi sangat menunjang terwujudnya tata kelola pemerintahan yang baik. Penyelenggaraan pemerintahan tidak hanya ditentukan oleh bagaimana pemerintah bekerja tetapi juga ditentukan oleh kebijakan yang diambil untuk kesejahteraan warga. Kebijakan yang dilaksanakan pun tetap harus berdasarkan AUPB dan peraturan perundangan yang berlaku.

Hotma P. Sibuea mengemukakan AAUPB lahir dari praktik penyelenggaraan negara dan pemerintahan sehingga bukan produk formal suatu negara seperti undang-undang. AAUPB lahir sesuai dengan perkembangan zaman untuk meningkatkan perlindungan terhadap hak-hak individu. Fungsi AAUPB dalam penyelenggaraan pemerintahan adalah sebagai pedoman atau penuntun bagi pemerintah atau pejabat administrasi negara dalam rangka pemerintahan yang baik atau good governance. ${ }^{13}$

\footnotetext{
${ }^{12}$ Aju Putrijanti, Lapon T. Leonard, and Kartika Widya Utama, 'Peran PTUN Dan AUPB Menuju Tata Kelola Pemerintahan Yang Baik (Good Governance)', Mimbar Hukum - Fakultas Hukum Universitas Gadjah Mada, 30.2 (2018), 277 <https://doi.org/10.22146/jmh.33056>.

${ }^{13}$ Hotma P. Sibuea, Asas Negara Hukum Peraturan Kebijakan Dan Asas-Asas Umum Pemerintahan Yang Baik (Jakarta: Erlangga, 2002).
} 
Perkembangan AUPB dapat dibagi dalam 3 fase. Fase pertama adalah bahwa secara historis penggunaan AUPB sudah berlangsung sejak lama. Penggunaan AUPB tidak didasarkan pada landasan hukum dalam bentuk normatif yaitu undang-undang atau peraturan perundangan lainnya, namun lebih diutamakan berdasarkan konsep, doktrin, kebiasaan yang timbul dalam praktik penyelenggaraan negara. Pada fase kedua, normativasi AUPB pertama kali dilakukan dalam Undang-Undang Nomor 28 Tahun 1999 tentang Penyelenggara Negara yang Bersih dan Bebas dari Korupsi, Kolusi dan Nepotisme. Ditegaskan bahwa pembentukkan Undang-Undang Nomor 28 Tahun 1999 tentang Penyelenggara Negara yang Bersih dan Bebas dari Korupsi, Kolusi dan Nepotisme merupakan bagian atau subsistem dari peraturan perundang-undangan berkaitan dengan penegakan hukum di bidang korupsi, kolusi dan nepotisme. Fungsi AUPB adalah untuk mewujudkan penyelenggaraan negara yang bersih dan bebas dari korupsi, kolusi dan nepotisme. Jadi, sebenarnya tidak mengatur sama sekali mengenai penyelenggaraan administrasi pemerintahan, yang menjadi urat nadi pelaksanaan pelbagai fungsi dan tugas pemerintah. Fase ketiga adalah setelah Undang-Undang Nomor 30 Tahun 2014 tentang Administrasi Pemerintahan disahkan sebagai perundangan yang pertama kali mengatur mengenai tata laksana pemerintahan yang sesuai dengan UUD NRI 1945 dan Pancasila. Hal-hal penting terkait penyelenggaraan pemerintahan mulai dari kewenangan, wewenang, AUPB, atribusi, delegasi, mandat, larangan penyalahgunaan wewenang, diskresi, keputusan berbentuk elektronis, izin, dispensasi, konsesi, konflik kepentingan, sosialisasi yang harus dilakukan oleh Pemerintah, standar operasional prosedur, syarat sahnya keputusan, legalisasi dokumen, sanksi administratif diatur secara jelas. ${ }^{14}$

Undang-Undang Nomor 30 Tahun 2014 tentang Administrasi Pemerintahan sangat diperlukan bagi semua pihak, baik pemerintah,

${ }^{14}$ Widjiastuti. 
masyarakat serta PTUN dengan faktor kepentingan yang berbeda tetapi secara keseluruhan memiliki persamaan yaitu untuk meningkatkan tata kelola pemerintahan yang baik. Selain berdasarkan peraturan perundangundangan, penyelenggaraan pemerintahan juga berdasarkan AUPB baik yang telah dicantumkan dalam perundang-undangan, maupun putusan hakim yang telah berkekuatan hukum tetap serta praktik pemerintahan. ${ }^{15}$

Asas-asas umum pemerintahan yang baik berkembang menjadi wacana yang dijadikan kajian para sarjana dan ini menunjukkan bahwa AAUPB merupakan konsep terbuka (open begrip). Sebagai konsep terbuka, maka akan berkembang dan disesuaikan dengan ruang dan waktu dimana konsep ini berada. Atas dasar ini tidaklah mengherankan jika secara kontemplatif maupun aplikatif AAUPB ini berbeda-beda antara satu dengan lainnya. ${ }^{16}$

\section{Pengertian Pelayanan Publik}

Menurut Undang-Undang Nomor 25 Tahun 2009 Pasal 1 Angka 1, pelayanan publik adalah kegiatan atau rangkaian kegiatan dalam rangka pemenuhan kebutuhan pelayanan sesuai dengan peraturan perundangundangan bagi setiap warga negara dan penduduk atas barang, jasa, dan/atau pelayanan administratif yang disediakan oleh penyelenggara pelayanan publik. ${ }^{17}$

Penyelenggara pelayanan publik itu sendiri ialah setiap institusi penyelenggara negara, korporasi, lembaga independen yang dibentuk berdasarkan undang-undang untuk kegiatan pelayanan publik, dan badan hukum lain yang dibentuk semata-mata untuk kegiatan pelayanan publik. Sedangkan penerima pelayanan publik ialah masyarakat dalam hal ini yang disebut dengan masyarakat ialah seluruh pihak, baik warga negara

\footnotetext{
${ }^{15}$ Putrijanti, Leonard, and Utama.

${ }^{16}$ Ichsan Syuhudi, 'Pena Justisia : Media Komunikasi Dan Kajian Hukum Implementasi AsasAsas Umum Pemerintahan Yang Baik', 17.1 (2017), 10-19.

${ }^{17}$ UU Nomor 25 Tahun 2009 Tentang"Pelayanan Publik", UU Nomor 25 Tahun 2009 Tentang"Pelayanan Publik", 2009.
} 
maupun penduduk sebagai orang-perseorangan, kelompok, maupun badan hukum yang berkedudukan sebagai penerima manfaat pelayanan publik, baik secara langsung maupun tidak langsung.

Pelayanan publik merupakan mandat bagi negara dalam memberikan pelayanan yang terbaik kepada masyarakat. Terdapat tiga pertimbangan mengapa pelayanan publik harus diselenggarakan oleh negara. Pertama, investasinya hanya bisa dilakukan atau diatur oleh negara, seperti pembangunan infrastruktur transportasi, pemberian layanan administrasi negara, perizinan, dan lain-lain. Kedua, sebagai kewajiban negara karena posisi negara sebagai penerima mandat. Dan ketiga, biaya pelayanan publik di danai dari uang masyarakat, baik melalui pajak maupun mandat masyarakat kepada negara untuk mengelola sumber kekayaan negara. ${ }^{18}$

\section{Peran Asas-Asas Umum Pemerintahan Yang Baik Dalam Pelaksanaan Pelayanan Publik}

Idealnya, semua pelayanan negara sebenarnya dibiayai sendiri oleh masyarakat melalui sistem asuransi dan perpajakan, dengan orientasi utama mendukung human investment. Konsep negara kesejahteraan itu adalah buah dari penerapan sistem ekonomi yang mandiri, produktif dan efisien dengan pendapatan individu yang memungkinkan masyarakat untuk menabung, setelah kebutuhan dasar dalam hidup mereka sudah tercukupi dengan pelayanan publik bebas biaya (gratis) yang diselenggarakan oleh pemerintah. Maka dari itu untuk mencapai cita-cita negara kesejahteraan (welfare state) tersebut haruslah diselenggarakan pelayanan publik (publik service) yang terjamin kualitasnya. Harapan sekaligus tuntutan masyarakat untuk mendapatkan pelayanan publik yang berkualitas, prosedur yang jelas, cepat dan biaya yang pantas terus mengemuka dalam perkembangan penyelenggaraan pemerintahan.

${ }^{18}$ Ainur Rofieq, 'Pelayanan Publik Dan Welfare State', Governance, 2 (2011). 
Harapan dan tuntutan tersebut muncul seiring dengan terbitnya kesadaran bahwa warga negara memiliki hak untuk mendapatkan pelayanan yang baik, dan kewajiban pemerintah untuk memberikan pelayanan publik yang berkualitas $^{19}$

Masyarakat memiliki hak sekaligus merupakan kewajiban pemerintah untuk memberikan pelayanan pemerintahan kepada masyarakat sebaik-baiknya. Dengan demikian, fungsi pelayanan publik tidak lain adalah tugas pemerintah dan negara untuk menciptakan kesejahteraan bagi rakyat Indonesia sebagaimana diamanatkan oleh UUD 1945. Fungsi pemerintahan yang efisien dan efektif sesungguhnya telah diatur dalam UU No. 28 tahun 1999 tentang Penyelenggaraan Negara yang Bebas dan Bersih dari Korupsi, Kolusi dan Nepotisme yaitu berdasar atas asas kepastian hukum, asas tertib penyelenggaraan negara, asas kepentingan umum, asas keterbukaan, asas proporsionalitas, asas profesionalisme dan asas akuntabilitas.

Hubungan hukum antara penyelenggara pelayanan publik dan masyarakat perlu diatur dengan tegas sehingga masing-masing pihak mengetahui hak dan kewajiban masing-masing dalam melakukan interaksi diantara mereka.

Sjachran Basah mengemukakan: "Walaupun Administrasi Negara memiliki keleluasaan dalam menentukan kebijakan-kebijakan, tetapi sikap tindaknya itu haruslah dapat dipertanggungjawabkan secara moral kepada Tuhan Yang Maha Esa, dan secara hukum harus memperhatikan batas atas dan batas bawah, dengan memperhatikan UUD 1945 sebagai tolak ukurnya."20

Pelaksanaan Asas-asas umum pemerintahan yang baik (AUPB) dalam sistem pemerintahan Indonesia akan berjalan dengan baik dan

\footnotetext{
${ }^{19}$ Muhaimin Muhaimin, 'Penguatan Penyelenggaraan Pelayanan Publik Melalui Penyelesaian Sengketa Informasi Publik', Jurnal Ilmiah Kebijakan Hukum, 12.2 (2018), 213 <https://doi.org/10.30641/kebijakan.2018.v12.213-226〉.

${ }^{20}$ Sjachran Basah, Perlindungan Hukum Terhadap Sikap Tindak Administrasi Negara. (Bandung: Alumni, 1992).
} 
lancar apabila didukung oleh adanya administrasi yang baik dan mantap. ${ }^{11}$ Asas-asas umum pemerintahan yang baik juga perlu diterapkan dalam pelaksanaan pelayanan publik dengan tujuan :

1. Terwujudnya batasan dan hubungan yang jelas tentang hak, tanggung jawab, kewajiban, dan kewenangan seluruh pihak yang terkait dengan penyelenggaraan pelayanan publik;

2. Terwujudnya sistem penyelenggaraan pelayanan publik sesuai dengan asas-asas umum pemerintahan dan korporasi yang baik;

3. Terpenuhinya penyelenggaraan pelayanan publik sesuai dengan peraturan perundang-undangan; dan

4. Terwujudnya perlindungan dan kepastian hukum bagi masyarakat dalam penyelenggaraan pelayanan publik.

Pada pasal 10 Undang-Undang Nomor 30 Tahun 2014 tentang Administrasi Pemerintahan menguraikan ruag lingkup AUPB yang berlaku dalam administrasi pemerintahan. Asas Umum Pemerintahan yang Baik yang dimaksud meliputi asas:

1. kepastian hukum. asas kepastian hukum merupakan asas dalam negara hukum yang mengutamakan landasan ketentuan peraturan perundangundangan, kepatutan, keajegan, dan keadilan dalam setiap kebijakan penyelenggaraan pemerintahan.

2. kemanfaatan. asas kemanfaatan maksudnya manfaat yang harus diperhatikan secara seimbang antara: (1) kepentingan individu yang satu dengan kepentingan individu yang lain; (2) kepentingan individu dengan masyarakat;(3) kepentingan Warga Masyarakat dan masyarakat asing; (4) kepentingan kelompok masyarakat yang satu dan kepentingan kelompok masyarakat yang lain; (5) kepentingan pemerintah dengan Warga Masyarakat; (6) kepentingan generasi yang sekarang dan kepentingan generasi mendatang; (7) kepentingan manusia dan ekosistemnya; (8) kepentingan pria dan wanita. 
3. Ketidakberpihakan. asas ketidakberpihakan adalah asas yang mewajibkan Badan dan/atau Pejabat Pemerintahan dalam menetapkan dan/atau melakukan Keputusan dan/atau Tindakan dengan mempertimbangkan kepentingan para pihak secara keseluruhan dan tidak diskriminatif.

4. Kecermatan. asas kecermatan dimaksudkan sebagai asas yang mengandung arti bahwa suatu Keputusan dan/atau Tindakan harus didasarkan pada informasi dan dokumen yang lengkap untuk mendukung legalitas penetapan dan/atau pelaksanaan Keputusan dan/atau Tindakan sehingga Keputusan dan/atau Tindakan yang bersangkutan dipersiapkan dengan cermat sebelum Keputusan dan/atau Tindakan tersebut ditetapkan dan/atau dilakukan.

5. Tidak menyalahgunakan kewenangan. asas tidak menyalahgunakan kewenangan adalah asas yang mewajibkan setiap Badan dan/atau Pejabat Pemerintahan tidak menggunakan kewenangannya untuk kepentingan pribadi atau kepentingan yang lain dan tidak sesuai dengan tujuan pemberian kewenangan tersebut, tidak melampaui, tidak menyalahgunakan, dan/atau tidak mencampuradukkan kewenangan.

6. Keterbukaan. asas keterbukaan adalah asas yang melayani masyarakat untuk mendapatkan akses dan memperoleh informasi yang benar, jujur, dan tidak diskriminatif dalam penyelenggaraan pemerintahan dengan tetap memperhatikan perlindungan atas hak asasi pribadi, golongan, dan rahasia negara.

7. Kepentingan umum. asas kepentingan umum adalah asas yang mendahulukan kesejahteraan dan kemanfaatan umum dengan cara yang aspiratif, akomodatif, selektif, dan tidak diskriminatif.

8. Pelayanan yang baik. asas pelayanan yang baik dimaksudkan sebagai asas yang memberikan pelayanan yang tepat waktu, prosedur dan 
biaya yang jelas, sesuai dengan standar pelayanan, dan ketentuan peraturan perundang-undangan.

Penerapan asas-asas umum pemerintahan yang baik dalam pelaksanaan pelayanan publik dalam rangka mewujudkan kesejahteraan masyarakat selain daripada yang disebutkan dalam pasal 10 UndangUndang Nomor 30 Tahun 30014 tentang Administrasi Pemerintahan menguraikan ruang lingkup AUPB yang berlaku dalam administrasi pemerintahan, antara lain $:^{21}$

1. Asas Keseimbangan. Asas ini menghendaki adanya keseimbangan antara hukuman jabatan dan kelalaian atau kealpaan seorang pegawai. Asas ini menghendaki pula adanya kualifikasi yang jela mengenai jenis-jenis atau kualifikasi pelanggaran atau kealpaan yang dilakukan oleh seseorang sehingga memudahkan penerapannya dalam setiap kasus yang ada dan seiring dengan persamaan perlakuan serta sejalan dengan kepastian hukum.

2. Asas Tidak Mencampuradukkan Kewenangan. Seorang pejabat pemerintahan memiliki wewenang yang sudah ditentukan dalam peraturan perundang-undangan baik dari segi materi, wilayah, maupun waktu. Aspek-aspek wewenang ini tidak dapat dijalankan melebihi apa yang sudah ditentukan dalam peraturan yang berlaku.

3. Asas Keadilan dan Kewajaran. Asas keadilan ini menuntut tindakan secara proporsional, sesuai, seimbang, dan selaras dengan hak setiap orang. Sedangkan asas kewajaran menekankan agar setiap aktivitas pemerintah atau administrasi negara memperhatikan nilai-nilai yang berlaku ditengah masyarakat, baik berkaitan dengan agama, moral, adat istiadat, maupun nilai-nilai lainnya.

AAUPB dapat dijadikan landasan atau pedoman bagi aparat pemerintah dalam menjalankan tugasnya, sekaligus sebagai alat uji bagi

${ }^{21} \mathrm{HR}$ 
lembaga peradilan dalam menilai tindakan pemerintah ketika ada gugatan dari pihak lain yang dirasakan merugikannya. Dengan kata lain, AAUPB secara teoritis sangat penting dalam mewujudkan pemerintahan yang bersih, berwibawa, dan berkualitas baik di pusat maupun di daerah. Secara yuridis, cerminan pemerintah yang demikian dapat dilihat dari produk hukum yang ditetapkannya, seperti dalam wujud perizinan daerah yang berwawasan lingkungan hidup. ${ }^{22}$

\section{Simpulan}

Dianutnya konsep negara kesejahteraan (welfare state) menjadikan pemerintah sebagai penanggung jawab kesejahteraan masyarakat. Dalam mewujudkan kesejahteraan tersebut pemerintah sebagai pemberi pelayanan publik harus memenuhi tujuan yang hendak dicapai dalam pelayanan publik tanpa membeda-bedakan. Dalam pelaksanaan pelayanan publik tersebut pemerintah hendaknya menjadikan asas-asas umum pemerintahan yang baik (AAUPB) sebagai pedoman dalam menjalankan tugasnya. Selain itu, masyarakat juga dapat menggunakan AAUPB untuk mengetahui apa yang menjadi hak dan kewajibannya sehingga tidak terjadi benturan antara pemerintah sebagai pemberi pelayanan publik dan masyarakat sebagai penerima pelayanan publik.

Asas-asas umum pemerintahan yang baik (AAUPB) yang dapat diterapkan dalam pelaksanaan pelayanan publik antara lain : asas kepastian hukum, asas kemanfaatan, asas ketidakberpihakan, asas kecermatan, asas tidak menyalahgunakan kewenangan, asas keterbukaan, asas kepentingan umum, dan asas pelayanan yang baik (sesuai dengan pasal 10 Undang Undang Nomor 30 Tahun 2014 tentang Administrasi Pemerintahan) serta terdapat asas tambahan yaitu : asas keseimbangan, Asas Tidak Mencampuradukkan Kewenangan, dan asas keadilan dan kewajaran (menurut Koentjoro Purbopranoto).

\footnotetext{
${ }^{22}$ Muhammad Azhar.
} 


\section{Daftar Pustaka}

Dewi, Dyah Adriantini Sintha, 'PENDAYAGUNAAN FREIES ERMESSEN PEJABAT PEMERINTAHAN DALAM KONSEP NEGARA KESEJAHTERAAN', 5.1 (2016), 184-94

Hamidi, Jazim, Penerapan Asas-Asas Umum Pemerintahan Yang Layak (AAUPL) Di Lingkungan Peradilan Administrasi Indonesia. (Citra Aditya Bakti, Bandung, 1999)

Hotma P. Sibuea, Asas Negara Hukum Peraturan Kebijakan Dan Asas-Asas Umum Pemerintahan Yang Baik (Jakarta: Erlangga, 2002)

HR, Ridwan, HUKUM ADMINISTRASI NEGARA (PT RajaGrafindo Persada, Jakarta, 2014)

Marbun, SF., Pembentukan, Pemberlakuan, Dan Peranan Asas-Asas Umum Pemerintahan Yang Layak Dalam Menjelmakan Pemerintahan Yang Baik Dan Bersih Di Indonesia (Bandung, 2001)

Muhaimin, Muhaimin, 'Penguatan Penyelenggaraan Pelayanan Publik Melalui Penyelesaian Sengketa Informasi Publik', Jurnal Ilmiah Kebijakan $\begin{array}{llll}\text { Hukum, } & 12.2 & \text { (2018), }\end{array}$ <https://doi.org/10.30641/kebijakan.2018.v12.213-226>

Muhammad Azhar, 'Relevansi Asas-Asas Umum Pemerintahan Yang Baik Dalam', Relevansi Asas-Asas Umum Pemerintahan Yang Baik Dalam Sistem Penyelenggaraan Administrasi Negara, 8.5 (2015), 274-87

Philipus M. Hadjon, and Et.al, Pengantar Hukum Administrasi Indonesia (Yogyakarta: Gadjah Mada University Press, 1993)

Putrijanti, Aju, Lapon T. Leonard, and Kartika Widya Utama, 'Peran PTUN Dan AUPB Menuju Tata Kelola Pemerintahan Yang Baik (Good Governance)', Mimbar Hukum - Fakultas Hukum Universitas Gadjah Mada, 30.2 (2018), 277 <https://doi.org/10.22146/jmh.33056>

Rofieq, Ainur, 'Pelayanan Publik Dan Welfare State', Governance, 2 (2011)

Sjachran Basah, Perlindungan Hukum Terhadap Sikap Tindak Administrasi Negara. (Bandung: Alumni, 1992)

Suratno, Sadhu Bagas, 'Pembentukan Peraturan Kebijakan Berdasarkan AsasAsas Umum Pemerintahan Yang Baik', E-Journal Lentera Hukum, 4.3, 164 <https://doi.org/10.19184/ejlh.v4i3.5499>

Syuhudi, Ichsan, 'Pena Justisia: Media Komunikasi Dan Kajian Hukum Implementasi Asas-Asas Umum Pemerintahan Yang Baik', 17.1 (2017), 10-19

UU Nomor 25 Tahun 2009 Tentang"Pelayanan Publik", UU Nomor 25 Tahun 2009 Tentang"Pelayanan Publik", 2009

Widjiastuti, Agustin, 'Peran Aaupb Dalam Mewujudkan Penyelenggaraan Pemerintahan Yang Bersih Dan Bebas Dari Kkn', Perspektif, 22.2 (2017), 96-110 $<$ http://jurnalperspektif.org/index.php/perspektif/article/view/614>

Yasin, Ikhsan Fatah, 'Eksistensi AAUPB Di Indonesia Dan Yurisprudensinya Dalam Perkara TUN', 8 (2018) 